\title{
Towards a Phonetic Description of Byelorussian
}

\author{
BY
}

ROLAND SUSSEX

It is encouraging to note, over the last decade or so, the increasingly active role of the Byelorussian Academy of Sciences in promoting and organizing synchronic and diachronic research into the structure of the Byelorussian language. The centre of this work has been the Academy's Institute of Linguistics, which now publishes, through 'Navuka i Technika', the journal Biełaruskaja Linhvistyka (1972-), as well as scholarly monographs. The latest of these, from the Laboratory of Experimental Phonetics in Minsk, is Padłužny \& Cekman's Huki biełaruskaj movy,* which has the distinction of being, if not the first full-length study of the sounds of Byelorussian, at least the first extended investigation of Byelorussian phonetics from an experimental viewpoint. ${ }^{1}$ It therefore adds an important new facet to our knowledge of Byelorussian phonetics, which has hitherto been mainly concerned with dialectology ${ }^{2}$ and normative descriptions in the 'kul'tura reči' pattern of Soviet Russian phonetics. ${ }^{3}$

If the book's subject matter is original, in a sense, its approach is conservative and conventional. It would probably have been unwise for the authors to choose otherwise. In a preliminary investigation, one can only gain from unequivocal techniques and well-tried methods of classification. The book contains four main sections: an introductory chapter on general articulatory phonetics and the physiology of speech (pp. 5-22); an analysis of the consonant phonemes (33-219) and vowel phonemes (220-49) of Byelorussian; and a brief summary of the main results (250-60). Although the authors devote most space to Byelorussian phonetics, they include many comparisons with other Slavonic languages - a merit also found in Cekman's diachronic work on palatalization (1970). Most of their comparative data is from Ukrainian, Russian and Polish, as is

* Padłužny, A. I., Cekman, V. M. Huki bietaruskaj movy. 'Navuka i Technika', Minsk, 1973. 263 pages.

1. For earlier studies, see Appel' (1880), Cekman (1970), Duravno (1929), Karskij (1885, 1908, 1927), Padłužny $(1968,1969)$, Padłužny \& Cekman (1972).

2. For dialectology, see Biryła (1957), Cekman (1968a-b), Dyjalektatahičny attas, Narysy..., Vajtovič (1968).

3. Biryła (1958), Jankoŭski (1961). 
generically and geographically proper. In balance, this is a careful and coherent analysis of Byelorussian in the context of the more familiar phonetic patterns of other Slavonic languages.

The experimental method is characteristic of the work as a whole, both in its scope and in its application. Seventeen informants were used in a variety of tests, involving mainly X-ray photography, palatograms, linguagrams and odontograms. There are reproduced, largely in line diagrams, as illustrations of aspects of the sounds under discussion. The experimental background is strongly influenced by the solid, but now somewhat outdated, work of Koneczna \& Zawadowski (1951 and 1956) and Skalozub (1963). The authors rely entirely on articulatory analysis, and make little mention of acoustic phonetics (p. 5), and no mention at all of perceptual phonetics; nor do they discuss the significance of all these areas in a total phonetic description. Easily visible articulatory movements are photographed - as with the posture of the lips in rounded vowels (pp. $266 \mathrm{ff}$.). Visually less accessible articulatory movements are investigated by $\mathrm{X}$-ray photography, in this case pictures taken transversely through the cheek; and by palatography, whereby the mouth is first sprayed with an adhesive, finely-ground powder containing charcoal-dust, a sound is pronounced and the inside of the mouth is then photographed, with the help of a spatula-shaped mirror, to record the location and amount of powder removed from the roof of the mouth (palatogram) and teeth (odontogram) by the tongue, and where the powder has adhered to the tongue (linguagram). These methods aim at an accurate location of all articulatory contacts within the oral cavity, and - with the help of X-ray pictures - to describe the posture of those parts of the vocal mechanism not actually in contact. Glottal, pharyngeal, uvular and (to a lesser extent) velar sounds depend more on the X-ray data.

The authors concentrate almost exclusively on phonetic segments. This limitation is defensible, at least for their purposes, since it allows a straightforward classification which runs parallel to treatments of Byelorussian segmental phonology (e.g., Padłužny (1969), Cekman (1970) ). A good example of the authors' method is their analysis of the nasals $/ \mathrm{n} /$ and $/ \mathrm{n}, /$ (pp. 142-63). They first define the basic articulatory characteristics of these sounds, and then consider various problems of phonetic specification. With $/ \mathrm{n} /$, there are the questions of the variable width of the tongue-dental contact, and the average limits of this contact. Evidence of X-ray cine-photography is cited to establish the velarization and the relatively lenis quality of the articulation, and the sound is specified as an apical, dental-and-alveolar velarized nasal. $/ \mathrm{n} /$ is then compared to $/ \mathrm{n}, /$, which emerges as a laminar prepalatal nasal, varying between speakers from dental-and-alveolar to palatal in extreme cases. The general evidence for $/ \mathrm{n} /$ consists of 16 palatograms, 8 linguagrams, and $13 \mathrm{X}$-ray line diagrams, covering the examples man, na, maná, nógi, šnur and péna; there are examples of articulations from several informants. For $/ \mathrm{n}, /$ there are 27 palatograms, 9 linguagrams and 10 X-ray line diagrams, covering ban', bánja, nja, njánja, manjá, bánju, 
jačménju, pen', sjënnja and zásen', again with data from several informants, and with an additional X-ray comparisons of Byelorussian /n,/ with Russian /n/, Ukrainian /n,/ and Polish /n,/ (' $n$ '). The authors conclude with a comparison of the articulatory properties of nasals in Byelorussian, Russian, Ukrainian and Polish.

This methodical accumulation and classification of data is a solid achievement, and one which will form a sound basis for future research in the field of Byelorussian phonetics. In addition, the authors' findings correct some important misconceptions in previous Byelorussian phonetic studies. The first, and most significant, of these concerns the status of the phonemes $/ \mathrm{ts}, /, / \mathrm{dz}, /, / \mathrm{s}, /$, and $/ \mathrm{n}, /$. Traditionally, in so far as one can speak of a tradition, these sounds have been regarded as apico-dental. Padłužny \& Cekman demonstrate conclusively that these are prepalatal laminar ('premediolingual') sounds - a result first reported in Padłužny \& Cekman (1972). These consonants therefore differ from $/ \mathrm{ts} /, / \mathrm{dz} /, / \mathrm{s} /, / \mathrm{z} /$ and $/ \mathrm{n} /$ not only in being unvelarized (Padłužny \& Čekman show that all hard consonants in Byelorussian are velarized), but also in their place of articulation. This is not the case with the labials $/ \mathrm{p} /, / \mathrm{b} /, / \mathrm{f} /, / \mathrm{v} /, / \mathrm{m} /$ and the apical $/ 1 /$, which have the homogeneous, but nonvelarized, palatalized counterparts in $/ \mathrm{p}, /, / \mathrm{b}, /, / \mathrm{f}, /, / \mathrm{v}, /, / \mathrm{m}, /$ and $/ 1, /$. On the other hand, $/ \mathrm{k}, /, / \mathrm{g}, /, / \mathrm{x}, /$ and $/ \gamma, /$ are analyzed as palatals (p. 253), a result which is phonetically doubtful; my observations, and the X-ray pictures (pp. 210-18) suggest that they are postpalatal, although Padłužny \& Cekman are certainly correct in distinguishing them clearly from the velar $/ \mathrm{k} /, / \mathrm{g} /, \mid \mathbf{x} /$ and $/ \gamma /$. The sounds $/ \check{\mathbf{s}} /, \mid \breve{\mathbf{z}} /, / \mathrm{ts} /$ and /dž/ are always hard and velarized. This leaves us with a list of 33 consonant phonemes:

\begin{tabular}{|c|c|c|c|c|c|}
\hline $\begin{array}{l}/ \mathrm{p}, / \\
/ \mathrm{d} / \\
/ \mathrm{ts}^{\prime \prime} / \\
/ \mathrm{dz} /\end{array}$ & $\begin{array}{l}/ \mathrm{b} / \\
/ \mathrm{s} / \\
/ \mathrm{dz} / 1 \\
/ \mathrm{j} /\end{array}$ & $\begin{array}{l}/ \mathrm{b}, / \\
\mid \mathrm{z} / \\
/ \mathrm{s}^{\prime \prime} / \\
\mid \mathrm{g} /\end{array}$ & $\begin{array}{l}/ \mathrm{v} / \\
/ \mathrm{n} / \\
/ \mathrm{z}^{\prime \prime} / \\
/ \mathrm{g}, /\end{array}$ & $\begin{array}{l}/ \mathrm{v}, / \\
/ \mathrm{r} / \\
/ \mathrm{n}^{\prime \prime} / \\
/ \mathrm{k} /\end{array}$ & $\begin{array}{l}/ \mathrm{m} / \\
/ 1 / \\
/ \check{\mathrm{s}} / \\
/ \mathrm{k}, /\end{array}$ \\
\hline
\end{tabular}

where " ", indicates prepalatal articulation. The sounds /f/, $|f /,| \gamma /,|\gamma|$, and $/ \mathrm{dz} /$ are held to be only marginally part of the Byelorussian sound system, on the grounds that they occur mainly in borrowed words. $/ \mathrm{h} /$ and $/ \mathrm{h}, /$ are properly regarded as dialectal variants.

The vowel system offers few surprises, and is treated rather briefly by Padłužny \& Cekman. Their results show four vowel heights and five degrees of tongue advancement at the systematic phonetic level:

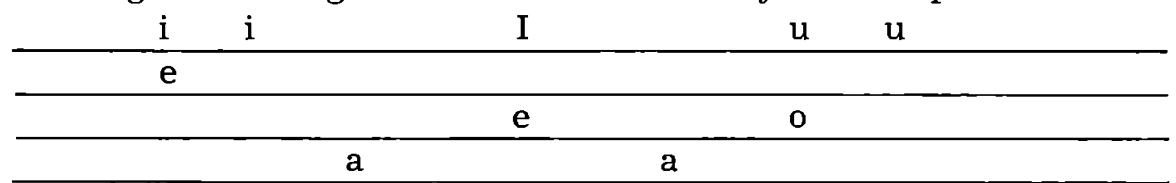

where the fronted versions of /e/ and /a/ are the variants which follow $/ \mathrm{j} /$, and thus follow the orthographic distinctions between ' $e$ ' and ' $g$ ' and between ' $a$ ' and ' $r$ '. The vowel height of $/ 0 /$ is perhaps slightly unexpected, but is certainly borne out by the data (pp. 239- 
41). It is more difficult to accept ' $\ni$ ' as a schwa, as is clearly indicated on p. 263, and the data (pp. 233 ff.) suggest a raised and fronted schwa. Furthermore, this presentation of the vowels fails to reveal that $/ \mathrm{u} /$, and to a lesser degree $/ \mathrm{i} /$, are not always as high as their cardinal counterparts (cardinal 3, first series, is rather oddly given as ' $E$ ' on p. 25). Much more serious is the omission of vowels in unstressed syllables, an unexpected oversight in a book otherwise well supplied with data.

On the other hand, the authors' concern for the 'articulatory basis' of Byelorussian reveals their interest in wider issues. Although they say disappointingly little on the relevance of their results to general phonetics, they do have some suggestive conclusions on the relation of Byelorussian to the phonetic structure of Ukrainian, Russian and Polish. Byelorussian is characterized by generally weaker articulatory movements than in Russian, which in turn is weaker than Ukrainian. High tongue position is again a characteristic of Byelorussian, since it affects about $75 \%$ of all sounds; and central tongue position is also typical, if slightly less striking statistically; this is a feature also found, although to a lesser degree, in Russian. Russian and Byelorussian also share velarized hard consonants, whereas this is less common in Polish (with the notable exception of $/ \mathrm{k} /$ ) or Ukrainian, which is also typified by more energetic articulatory movements, and by a more forward position of articulation than is usual in Byelorussian. These data - and I have only given some of the general conclusions - are of course only as good as the experimental evidence supporting them (see below). But they do constitute an important step towards a better understanding of comparative Slavonic phonetics.

As these data suggest, the authors' most impressive contribution is to the study of the place of articulation in Byelorussian consonants, and to a lesser extent in the vowels. There are, nevertheless, a number of places in this book where the authors have not extracted the maximum information from their experimental material. This is partly due to their reliance on certain techniques without commenting on the practical and theoretical limitations of these methods; and partly to the way in which they interpret the data. The limitations of palatography are now well known and agreed on in the field of experimental phonetics. ${ }^{4}$ Palatograms are undeniably useful in identifying broad-scale place of articulation data. But the method is inherently unnatural. The articulation is made under artificial and generally decontextualized conditions, and the accuracy of the measurements obtained is subject to a number of variables which are hard to control. Speakers differ in the way in which they pronounce sounds, even under natural and identical conditions: factors like degree of stricture, the amount of contact, and the energy of articulation can, and do, vary widely. And when sounds are pronounced under abnormal conditions, as with shouting, whispering, or with changes of speed, the differences are even more marked. These

4. Abercrombie (1965), Fujimura et al. (1973). 
variations can, in principle, be averaged out to give a median place and area of articulation. But this process becomes much more difficult when we compare the articulations of several speakers, with different sizes and shapes of palate and tongue - factors which vary widely with age, sex, and physical development. Padłužny \& Cekman fail us here, since they give no method of reliable comparison, other than an impressionistic contrast of shaded areas where the powder has been affected. Nor do they tell us enough about the conditions under which the tests were made, the instructions given to the informants, the physical characteristics and social backgrounds of the speakers, the speed of the spoken segments tested, and other aspects of the experimental situation. Nor do they offer any method of quantifying the results, which is the only practicable way of making reasonable comparisons between speakers. There is a method for doing this, whereby lines are drawn across the palatogram connecting the gaps between the teeth, the resulting squares are numbered, and the size and location of shaded or unshaded areas can then be stated with at least some comparability. A similar procedure could, again in principle, be applied to odontograms, although here, again, we come across the problem of widely differing dental structure among informants. It is more difficult to apply quantitative measurements to linguagrams, since $(a)$ the powder traces on the tongue tend to be blurred at the edges, $(b)$ the tongue varies considerably in size, shape and mobility among speakers, and (c) the posture it adopts in the mouth for the formation of an individual segment can vary within fairly broad limits, often depending on the phonetic context. All of these facts reduce the reliability of Padłužny \& Cekman's results. But it still leaves us with a valuable, if less precise, notion of the place and extent of the articulation of Byelorussian phonetic segments.

There is, however, a more general shortcoming in Huki biełaruskaj movy, and one which is important for future work on Byelorussian phonetics. It is always presumptuous, in a sense, to accuse authors of omissions. And Padłužny \& Cekman openly intend their study to be 'a first step towards the construction of a scientific descriptive phonetics' of Byelorussian (p. 3). But it is limiting, and possibly misleading, to define sounds purely as segments. However valuable for the purposes of preliminary classification, this methods obscures the value - and limitations - of segmental analysis by ignoring the relation between segmental and non-segmental phonetics, and by diverting attention from factors like transition-phenomena and the phonetic context. The field of articulatory phonetics is bounded by number of other areas of phonetic investigation, more or less intimately connected with articulatory studies. Some of these areas, including many of those loosely termed 'suprasegmental', might excusably be omitted from a basically articulatory investigation: topics like intonation, pitch and length. On the other hand, the place and manner of articulation can be critically affected by factors like tessitura, speed of utterance, volume, energy or articulation, and stress - there is, for example, no treatment of consonants in unstressed syllables. It 
is the absence of these aspects of sound structure which reduce the value of Padłužny \& Cekman's findings.

An obvious example concerns the reaction between place and manner of articulation. Energetically released plosives are similar to affricates in their release mechanism; the opposite occurs with lenis articulations - a factor mentioned in the comparison of Byelorussian, Ukrainian, Russian and Polish consonants, but not in connexion with voiced/voiceless oppositions in Byelorussian. Padłužny \& Čekman, indeed, have a very 'all-or-none' view of articulatory features. This is particularly clear in their analysis of manner of articulation, with its very uncritical acceptance of clear boundaries between manner classes like plosive and fricative. It would be most interesting to have more data on varying degrees of energy and stricture in consonant clusters, and on differing degrees of voicing and devoicing, to name two obvious omissions. It would be even more helpful to have acoustic evidence in these and other areas (cf. Isačenko (1968)). And Padłužny \& Cekman have an unnecessarily restricted concept of phonetic environment. They do not tell us enough about labialization of consonants in the enviroment of labialized vowels: compare Russian [ $\mathrm{k}^{\mathrm{w}} \mathrm{ot}$ ] with Czech and Slovak [kot]. Nor do they deal satisfactorily with the nasalization of vowels in the environment of nasal consonants, or with the effect of surrounding palatalized consonants on vowel articulations, as in Russian ['p'atka] 'heel' but [p'æt,] 'five'. In addition to these specific aspects of analysis, it is only just to observe that there are many issues in a broader articulatory framework which are not studied, and often not mentioned, here: glottal processes, subglottal pressure, air-flow and air-pressure, to mention only those directly relevant to Byelorussian. And there are many problems in general phonetics which bear on the issues discussed here, especially acoustic methods.

Nevertheless, Huki biełaruskaj movy remains a sound beginning for an articulatory phonetics of Byelorussian. Its data on palatals, palatalization and velarization represent concrete achievements. It also allows us to look a little more clearly towards the more remote goal of a comparative phonetic typology of the Slavonic languages. Padłužny \& Cekman do attempt to place their findings in the context of other Slavonic languages, although only in an episodic and informal manner. They can be criticized for leaving a great deal untouched; and it is certainly true that their experimental techniques are unlikely to take us much further - apart from dialect and idiolect studies - unless new X-ray techniques for investigating the larynx are discovered. Nor is it likely that their results will allow really precise comparisons in the field of Slavonic phonetics, especially in the absence of quantifying techniques for data analysis. But this is still a valuable work, full of data and keen observation. Future students of experimental Byelorussian - and Slavonic phonetics will appreciate such carefully-laid foundations. 


\section{BIBLIOGRAPHY}

ABERCROMBIE, D. 'Direct palatography', in Studies in Phonetics and Linguistics, London, 1965, pp. 125-30.

APPEL', K. 'O belorusskom narečii', RFV 3, 1880, pp. 1-2.

BIRYŁA, M. V. 'Etimalahična miakkija gubnyja zyčnyja ŭ biełaruskich narodnych havorkach', PIM Bel 3, 1957, pp. 71-93.

BIRYŁA, M. V. 'Da pytańnia ab farmiravańni i važnejšych normach biełaruskaha litaraturnaha vymaŭleńnia', Veści AN BSSR, 3, 1958, pp. 165-76.

CEKMAN, V. M. 'Da pytańnia ab "Šapialavych" $s$ i $z$ ŭ biełaruskich havorkach', VBelGrN 3, 1968a, 83-9.

CEKMAN, V. M. 'Natatki ab procipastaŭleńniach pa ćviordaści-miakkaści ŭ niekatorych paŭdniovabiełaruskich havorkach', in Linhvistyčnyja dasledavańni, Minsk, $1968 \mathrm{~b}$, pp. 6-18.

CEKMAN, V. M. Historyja procipastaŭleńnia pa ćviordaści-miakkaści u biełaruskaj movie, Minsk, 1970.

DURNAVO, M. M. 'Uvahi da biełaruskaj fanetyki', Zapiski adździeła humanitarnych navuk Bielaruskaj Akademii Navuk, Minsk, 2, 9, 1929, pp. 68-72.

Dyjalektatahičny atłas bielaruskaj movy, ed. R. I. Avaniesaŭ, K. K. Krapiva \& Ju. F. Mackievič, Minsk, 1963.

FUJIMURA, O., TATSUMI, I. F. \& KAGAYA, R. 'Computational processing of palatographic patterns', JPhon, 1, 1973, pp. 47-54.

ISAČNKO, A. V. Spektrografická analýza slovenských hlások, Bratislava, 1968.

JANKOŬSKI, F. Pytańni kultury movy, Minsk, 1961.

KARSKIJ, Je. F. Obzor zvukov i form belorusskoj reči, Moscow, 1885.

KARSKIJ, Je. F. Belorusy, II. 1, Istoričeskij očerk zvukov belorusskogo jazyka, Warsaw, 1908.

KARSKIJ, Je. F. 'Deux points de phonétique blanc-russe', RESl, 6, 1927, pp. 22-6.

KONECZNA, H. \& ZAWADOWSKI, W. Przekroje rentgenograficzne gtosek polskich, Warsaw, 1951.

KONECZNA, H. \& ZAWADOWSKI, W. Obrazy rentgenograficzne glosek rosyjskich, Warsaw, 1956.

KUZNECOVA, A. M. 'Nekotoryje voprosy fonetičeskoj charakteristiki javlenija 'tverdosti-mjagkosti soglasnych v russkich govorach', in: Vysotskij, P. S. (ed.), Eksperimental'no-fonetičeskoje issledovanije russkich govorov, Moscow, 1969, pp. 33-137.

KUZNECOVA, A. M. 'Neskol'ko zamečanij po povodu assibiljacii soglasnych $t^{\prime}, d^{\prime} \mathrm{v}$ slavjanskich jazykach', in Issledovanija po slavjanskomu jazykoznaniju, Moscow, 1971, pp. 162-6.

Narysy pa biełaruskaj dyjalektałohii, ed. R. I. Avaniesaŭ, Minsk, 1964.

PADEUŽNY, A. I. 'Ab fanematyčnym pryncypie ŭ biełaruskaj arfahrafii', in Linhvistyčnyja dasledavańni, Minsk, 1968, pp. 19-25.

PADEUŽNY, A. I. Fanałahičnaja sistema biełaruskaj litaraturnaj movy, Minsk, 1969.

PADEUŽNY, A. I. \& CEKMAN, V. M. 'Ab asablivaściach utvareńnia hukaŭ ts', $d z^{\prime}, s^{\prime}, z^{\prime} \breve{u}$ biełaruskaj litaraturnaj movie', Biełaruskaja Linhvistyka, 1 , 1972, pp. 28-48.

SKALOZUB, L. G. Palatogrammy i rentgenogrammy soglasnych fonem russkogo jazyka, Kiev, 1963.

VAJTOVIC, N. T. Nienaciskny vakalizm narodnych havorak Bietarusi, Minsk, 1968. 